\title{
Composites of polyethylene and polyurethane blended with rice residues derived silica
}

\author{
(C) Duy Hung Nguyen,,${ }^{1}$ Lyubov A. Zenitova,,${ }^{1+}$ Hong Nghia Ngo, ${ }^{1}$ \\ Quang Dien Le, ${ }^{2}$ and Thi Hien Nguyen ${ }^{3}$ \\ ${ }^{1}$ Department of Technology of Synthetic Rubber. Kazan National Research Technological University. \\ Karl Marx St., 72. Kazan, 420015. Republic of Tatarstan. Phone: +7 (962) 550-46-19, +7 (843) 231-42-51. \\ E-mail:ndhungdt@gmail.com,liubov_zenitova@mail.ru \\ ${ }^{2}$ Department of Cellulose and Paper Institute of Chemical Engineering. Hanoi University \\ of Technology. Dai Co Viet St., 1. Hai Ba Trung, Ha Noi, Viet Nam. \\ Phone:+7 (843)8684955.E-mail: lequangdients@gmail.com \\ ${ }^{3}$ Faculty of Environmental Technology. Viet Tri University of Industry. Viet Nam. \\ Phone: +84 2103829247. E-mail: hiennt.cnmt@vui.edu.vn
}

*Supervising author; ${ }^{+}$Corresponding author

Keywords: rice husk, rice straw, silicon dioxide, polyurethane, polyethylene, physical and mechanical properties.

\section{Abstract}

Rice husks and rice straw are potential residues of rice production. Their composition consist a large amount of silica with other compounds such as cellulose, lignin, hemicellulose. In the refinery of these residues the separation of silica from these residues can provide high economic efficiency, and also solves the problem of environmental pollution. The composition and dimensions of prepared silica dioxide, which were determined by modern analytical methods such as SEM, XRD and IR, showed that the purity of $\mathrm{SiO}_{2}$ was more than $90 \%$ and grain dimensions were about nanometers. In this study, the rice residues derived $\mathrm{SiO}_{2}$ was used as a 5\% (w/w) blend for polyurethane and low pressure polyethylene. The choice of polyethylene for composites fabrication was based on its relatively plain structure and good technological properties. The polyurethane has choose as a polymer with good resistance to abrasive wear, high elasticity, and high resistance to weathering. Evaluation of the physic mechanical properties of composites showed that the strength of polyethylene based composite samples blended with $1 \%(\mathrm{w} / \mathrm{w})$ silica dioxide increased up to $33 \%$, in the case of polyurethane composites blended with $0.5 \%$ $(\mathrm{w} / \mathrm{w})$ silica dioxide the strength increased up to $21 \%$. In comparison with same composites blended with classical aerosil in the equivalent dosage, the strength of polyethylene based composites was higher than about $9 \%$, in the case of polyurethane based composites it was higher than about $16 \%$. Considering the saving of natural resources and ecological expediency, the replacing of synthetic silica dioxide by rice residues derived silica dioxide of is of considerable interest.

\section{References}

[1] X. Li, Z. Cao, Z. Zhang, H. Dang. Surface-modification in situ of nano-SiO2 and its structure and tribological properties. Appl. Surf. Sci. 2006. Vol.252. P.7856-7861. (russian)

[2] P. Rait, A. Camming. Polyurethane Elastomers. Leningrad: Chemistry. 1973. 152p. (russian)

[3] I.V. Kovalevskaya, T.R. Safiullina, L.A. Zenitova. Structure and properties of polyurethane filled with silica gel type SKU-PFL. Journal of Kazan Technological University. 2012. Vol.15. P.140-143. (russian)

[4] A.A. Farvazeva, D.V. Sugonyako, D.H. Nguyen, H.N. Ngo, L.A. Zenitova. Properties of filled polymer compositions based on polyethylene and plasma-treated silicon dioxide. Journal of Kazan Technological University. 2017. Vol.20. P.53-57. (russian)

[5] F. Wang, L. Feng, H. Ma, Z. Zhai, Z. Liu. Influence of nano-SiO $\mathrm{S}_{2}$ on the bonding strength and wear resistance properties of polyurethane coating. Sci. Eng. Compos. Mater. 2019. Vol.26. P.77-83.

[6] E.M. Gotlib, E.R. Galimov, N.Ya. Galimova, E.E. Sharafutdinova, M.M. Ganiev, I.F. Gumerov. Properties and application in mechanical engineering. KNRTU. 2016. P.248. (russian)

[7] L.A. Zenitova, V.T. Novoseltsev, P.A. Kirpichnikov. Production of polyurethane composite materials filled with oxides of silicon and aluminum, and coatings based on them: Author's abstract. dis ... tech. of science: 05.17 .06$.

[8] A.A. Namakshynas, O.D. Khorozova, V.V. Sakharov. IR spectroscopic study of amorphous nano-sized layers of silicon dioxide during thermal decomposition of polyorganosiloxanes. Advances in Chemistry 

and Chemical Technology. 2016. Vol.30. P.74-76. (russian)

[9] M.V. Chibisova, V.G. Berezkin. Determination of synthetic dyes in food products by thin-layer chromatography, UV and IR spectroscopy. Sorption and Chromatographic Processes. 2011. Vol.11. P.219-228. (russian)

[10] Baraeva L.R., Akhmetova R.T., Khatsrinov A.I., Yusupova A.A. The technology of iron polysilicat sulfid based on sulfur of the petrochemical complex and amorphous silicon dioxide. Monographs. Kazan: KNITU. 2013. P.80. (russian)

[11] B.N. Khlebtsov, V.A. Khanadeev, I.E. Pylaev, N.G. Khlebtsov. The method of dynamic light scattering in studies of silicat and gold nanoparticles. News of Saratov University. New series. Physics Series. 2017. Vol.17. No.2. P.71-84. (russian)

[12] E.A. Kiyanenko, L.A. Zenitova, N.Z. Mingaleev, and O.A. Nikolayeva. The influence of fillers on process of formation and structure of the polyurethane coatings based on polyethers. Butlerov Communications. 2015. Vol.41. No.1. P.147-151. DOI: 10.37952/ROI-jbc-01/15-41-1-147

[13] V.A. Malanchuk, E.A. Astapenko, N.A. Galatenko, R.A. Rozhnova. Results of the study of the physicomechanical properties of a biodegradable polymer used in reconstructive surgery of the bones of the maxillofacial region. Herald of Problems Biologia i Meditsini. 2013. Vol.1. P.304-308.

[14] H. Chen, F. Wang, C. Zhang, Y. Shi, G. Jin, S. Yuan, Preparation of nano-silica materials: The concept from wheat straw. J. Non. Cryst. Solids. 2010. Vol.356. P.2781-2785.

[15] M.Z. Abdullin, D.I. Fazylova, L.A. Zenitova, I.Sh. Abdullin, M.F. Shaehov. Application of shungite as a filler of rolled polyurethanes. Journal of Kazan Technological University. 2010. Vol.13. No.11. P.118-123. (russian)

[16] Duy Hung Nguyen, L.A. Zenitova, Quang Dien Le, and Do Tien Thinh Bui. Use of burn rice residues for production of nanosilica. Butlerov Communications. 2019. Vol.57. No.3. P.155-161. DOI: 10.37952/ROI-jbc-01/19-57-3-155 